\title{
Dōgen and the Linguistics of Reality
}

\author{
Rein Raud
}

check for updates

Citation: Raud, Rein. 2021. Dōgen and the Linguistics of Reality. Religions 12: 331. https://doi.org/ $10.3390 /$ rel12050331

Academic Editor: George Wrisley

Received: 29 March 2021

Accepted: 4 May 2021

Published: 10 May 2021

Publisher's Note: MDPI stays neutral with regard to jurisdictional claims in published maps and institutional affiliations.

Copyright: (c) 2021 by the author Licensee MDPI, Basel, Switzerland. This article is an open access article distributed under the terms and conditions of the Creative Commons Attribution (CC BY) license (https:// creativecommons.org/licenses/by/ $4.0 /)$.
School of Humanities, Tallinn University, 10120 Tallinn, Estonia; rein.raud@tlu.ee

Abstract: The goal of this article is to show how Dōgen's views of language, perhaps the most "mystical" part of his thought at first glance, can be interpreted in a framework that is wholly rational in the broader sense of the word. Dōgen belongs to a pansemioticist tradition and indeed maintains that being is tantamount to signification, but unlike previous pansemioticists, such as Kükai, he does not posit a signifying subjective Other to whom the "message" of reality can be attributed. In Dōgen's view, the meaningfulness of an event is a concomitant characteristic of its very reality, because the availability of reality for us to experience is already a linguistic phenomenon. The article argues that this is not a mystical thesis, but a view that can also be articulated in a more familiar and fully rational idiom, and that it bears similarities with many different Western thinkers and theorists, such as Wittgenstein, Heidegger, Gadamer, Peirce, Jakobson, and others.

Keywords: Dōgen; Shōbōgenzō; Buddhist philosophy of language; signification; pansemioticism; negativity; rationality

\section{Introduction}

There is a tradition in Western Buddhist studies that tries to explain all seemingly paradoxical and self-contradictory ideas away by claiming that they are impenetrable from the point of view of the unenlightened reader, but nonetheless make perfect sense from the alleged "perspective of the bodhisattva" (Nagatomo 2000, p. 224), which the researcher imagines, but does not necessarily claim, to share. This move supposedly exempts the researcher from the responsibility to analyze and clarify the more perplexing passages in the texts under scrutiny and thereby contributes to the delegitimization of Asian philosophical thought, allowing it to be classified as "mystic wisdom", inferior to Western philosophical pursuits (see Van Norden 2017 for a critical discussion of this intellectual stance). The same attitude has also occasionally been applied to the work of 道元 Dōgen, which is notoriously difficult-labeled a "mystic", he is being compared to St. Francis (Ruhl 2020) or Meister Eckhardt (Dallh 2018; Zelinski 2007), as someone who speaks cryptically about the unfathomable and does not therefore need to make sense in rational terms. However, Heejin Kim, who is perhaps somewhat responsible for this trend by having called Dōgen a "mystical realist" in the subtitle of his influential monograph, has stressed that the "mystical realism" he had in mind was "neither transcendental nor immanental in the conventional fashion but realizational" (Kim 2004, p. 67), i.e., characterizing the state of mind of the practitioner rather than Dōgen's broader ideas about reality. Moreover, Kim has also emphatically underscored that Dōgen's thought was never "a dissolution of the conscious mind, as in the case of a certain type of mysticism... The critical mind was never forfeited in Dōgen's thought" (Kim 2004, p. 104). Indeed, there is no excuse for dismissing the philosophical aspects of Dōgen's work as "mystical" simply because they are difficult to understand.

Elsewhere (Raud 2012, 2015, 2019), I have offered interpretations of some of the key concepts and positions of Dōgen's thought, trying to show that they indeed do not imply a mystical understanding of reality and are completely rational, if we agree to include in the domain of the rationally graspable also such unquestionably real, but not discretely measurable, phenomena as, for example, aesthetic katharsis, the ecstatic 
mood of a dance party or a heated political rally, or the bodily intuitions of athletes playing in a team. Discursive conceptual descriptions and explanations of such experiences, I maintain, are rational by definition, even if these experiences themselves are not produced by or wholly encapsulated in rational thought understood in the narrow sense of the word. It is true that Dōgen's discourse is hardly transparent and was evidently perceived to be rather obscure already in its own times. And yet, when we delve through the difficulties of form, we regularly find ideas there that are focused precisely on an intellectually coherent and consistent explication of a mental state of non-egocentric openness, which is just as describable in rational terms as aesthetic or corporal intuitions are.

In other words, "rationality" should be a characteristic not of the topic, but of the manner of discussion. In the present context, the term will be referring to the character of ideas that can in principle be formulated in a shareable and reasonably rigorous discourse, i.e., one relying on definable terms rather than ideas claimed to remain beyond the limits of human understanding and making sense, for example, only from the "perspective of the bodhisattva". This includes also ideas that cannot be formulated according to discrete standards of measurement, and can even be counterintuitive, such as the conceptual adventures of higher mathematics and contemporary physics. Such a rationality may also characterize particular ideas even when the overall context of their expression does not emphasize rationality for historical reasons, or when the form of discourse does not appear to us as such, for example, because of its use of examples and metaphors that look irrational in our present context ${ }^{1}$. Consequently, the "rationality" of the expressed thought implies that it is possible, in principle, to disassociate an argument from its original discursive context in order to render it comparable to, and appraisable in the context of, a larger body of ideas. Incidentally, this is why a philosophical argument can not only also make sense to, but even be developed further by people who do not share the convictions of the author who has originally advanced it; thus, for example, the objective idealism of Hegel can serve as the ground on which the historical materialism of Marx and Engels relies for its structures of thought.

Of course, Dōgen's discourse is articulated in the framework of the Buddhist institution and its broader cultural functionality, which differs from Western academia (the institutional context of the present writing) quite remarkably-and clearly the two are not grounded in the same type of rationality in the same way. But this does not preclude us from treating Dōgen's thought as rational. We should also note that from among the life trajectories actually available to Dōgen in early Kamakura Japan, the Buddhist "path" was the only one compatible with philosophical pursuits. Moreover, it cannot be asserted that he commits to this tradition uncritically. On the contrary, more often than not, his interpretations of the source texts are rather unorthodox and he often criticizes previous practitioners of the teaching, not because he thinks he is right and they are wrong, but because of their unwillingness to penetrate beyond the verbal surface of the received views. Such an "unphilosophical" attitude may even cause serious problems, which Dōgen calls "buddha-addiction" and "dharma-addiction" (Dōgen 1972, vol. I, p. 87) — that is, uncritical commitment to transmitted ideas and concepts taken at their face value.

Again, while it is correct to say that Dōgen's aims were primarily practical, or that the main aim of his activity was to arrive at a view of how the human life should be properly lived, it stretches things to call this praxis" "soteriological" or "salvific", which implies being "saved" (for example, from posthumous punishment in hell). The latter can still very probably have been the motivation of the bigger part of his audiences, and it may have been a felt necessity for Dōgen to adjust his message to the horizon of expectations of his listeners, but the often-repeated goal of Dōgen himself was to attain a much more rationally understood enlightenment, a state of mind that would be free of conceptual entanglements and able to directly tackle reality, not a 
transcendent Other lurking behind it, as well as to carry that mindset over to all practical ways of engaging with the world. In short, it seems just to say that Dōgen's views of his own thought are approximately comparable to those of Wittgenstein, who writes:

Why is philosophy so complicated? It ought, after all, to be completely simple. Philosophy unties the knots in our thinking, which we have tangled up in an absurd way; but to do that, it must make movements which are just as complicated as the knots. Although the result of philosophy is simple, its methods for arriving there cannot be so ... The complexity of philosophy is not in its matter, but in our tangled understanding. (Wittgenstein 1975, p. 52)

There are, however, two important and interrelated aspects of Dōgen's thought that seem to defy the evaluation of it as rational in principle. These are his concept of the teaching as transmitted by "Buddhas and ancestors", and his view of language. It is my goal in this article to show how these, too, are parts of the broader rational framework in which I have been interpreting Dōgen's thought. The concepts are connected in that "Buddhas and ancestors" are usually cited as the instances articulating verbal statements conducive to proper understanding. (They are also often mentioned in the context of appropriate praxis, but, as I hope will become evident later, there is no real dichotomy here.) Language, on the other hand, seemingly takes on the role of the fibers that unify the micro- and the macrocosmic. On the one hand, it is the organizing principle of the internal process of a person that, if purified from tangled understandings, is able to express the attainment of the enlightened state of mind. On the other hand, it is approximated to the principle upholding reality as such, which consists in permanent signification. It is this activity of signification through which the non-differentiation of the particular and the universal is articulated ${ }^{3}$.

This, however, is where we need to ask whether such pansemioticism does not amount to the positing of a transcendental Other, a level of ontologically mindindependent "Buddhas and ancestors" from which this signification proceeds. Previous Buddhist thinkers who have proposed a similar doctrine, such as Kükai, have answered this question in the unfaltering affirmative. According to Shingon doctrine, the Buddha Mahāvairocana, someone with a body, mind, will and personal history (see Hakeda 1972, pp. 81-93; Abe 1999, p. 131 and passim), is the cosmic and yet subjective entity behind reality as-signification, and communication with that Buddha is potentially a two-way street. With Dōgen, however, matters are even more complicated.

\section{Dōgen's Ideas of Language and Communication}

In the Chan/Zen tradition, two complementary attitudes towards language have been apparent since its inception. On the one hand, there is the idea of "a separate transmission not relying on words and letters"; on the other, however, there is the idea of "living words" that speak directly from mind to mind and are able to transmit messages that reified concepts, or "dead words", are incapable of conveying. The expression "dead words" has been adopted from a passage in the Dharmakşema translation of the Mahāparinirvāna sūtra (Takakusu and Watanabe 1961a, vol. 12, p. 415c03), although, there, the expression means "words of death" rather than words that are somehow dead themselves. In due course, the idea became current in Chan lore and the sentence "he was engaged in living speech, not in dead speech" even became a sort of a stock phrase to describe someone's superb expression (for example, in the 碧眼録 Biyanlu, the expression is met 11 times). It is thus not the "words and letters" themselves that the tradition objects to, but the inclination to rely on them unquestioningly, to the point that they become "dead", context-independently repeatable, reified, and therefore unable to address immediate reality at all. 
We can find the same type of two-tiered conceptual structure also in Dōgen's work. But there are important differences. Dōgen uses primarily two words for linguistic utterances, 言 gon and 道得 dōtoku (sometimes also transcribed dōte), but these do not correspond to "dead" and "living" words as defined above. Gon can be used for any self-identical verbal construct that can be extracted from its original context. For example, quotes from sutras or samples of Zen lore are typically called "Buddhaexpressions" (butsugon) using this word. Thus, gon are by themselves neither "dead" nor "living"; it always depends on how they are used and interpreted. Dōtoku, on the other hand, is a different matter. In principle, it denotes the equivalent of "living words", but even more radically than previous Zen sources have treated the expression.

The first character of the expression has the meaning of "way", or, in various philosophical traditions, "ineffable cosmic order" or "the way how things should be" and in Buddhist usage also means the teaching, as in 学道 gakudo "studying the (Buddhist) Way", an expression frequently used in Dōgen's text. However, just as with Greek logos, the word also means "to speak, to express, to name". The other character means primarily "to get" and, by proxy, "to achieve", "to attain", and in combination they thus mean "formulated attainment", "attained expression of cosmic order". In conventional Zen usage, the word dōtoku is normally used as a technical term referring to an expression that captures the essence of the teaching adequately (Zengaku Daijiten Hensanjo 1985, p. 937). Dōgen, however, has replaced the verb-object relationship between the two characters with a relationship of predication, making the word mean "attainment-is-expression" or "expression-as-attainment" as a result (see Raud 2013 for a more technical description of how this happens). The idea is that certain linguistic (or, for that matter, non-linguistic) expressions are themselves the attainment, the arrangement of things in authentic relation to each other, not the expression of someone's attainment or a testimony that someone has achieved a state of mind that they didn't have before-because that would necessarily imply a certain duality between someone and mind, someone and attainment. As Ishii Kyōji has argued, dōtoku is the "linguistification" of the universal and natural law embodied in the Buddhist teaching, and the existential moment (有時 $u j i$ ) is the site in which it takes place as a phrase (Ishii 2001, p. 197) ${ }^{4}$. Ralf Müller translates Dōgen's dōtoku as "the perfect expression", specifying that "perfect does not mean such perfection here that would be closed and absolute, but rather 'perfect' in the sense of modelling a certain situation in its totality, something that has been grasped in a moment and will then again flow asunder" (Müller 2013, p. 271).

Dōgen has dedicated a whole eponymous fascicle of "The Core Transmission" ${ }^{5}$ (正法眼蔵 Shōbōgenzō) to the discussion of this notion. It is indeed obvious from the very beginning that much more than just words is at stake:

All Buddhas and all ancestors are attainment-expressions. This is why Buddhas and ancestors, when picking out Buddhas and ancestors, necessarily demand: is the attainment-expression present or not? This demand is made with the mind, made with the body, made with the whisk and staff, made with the pillar and the lantern. Who is not a Buddha or an ancestor has no attainment-expression, because this would be out of place. Such an attainment-expression cannot be acquired by following others, it cannot be produced by one's own force-only when there is the exhaustive understanding of Buddhas and ancestors is the attainment-expression of Buddhas and ancestors also present. (Dōgen 1972, vol. I, p. 384)

When Dōgen speaks about "Buddhas and ancestors" (佛祖 busso), we should not think of the term as referring to historical persons, whose teaching he would be transmitting. Neither, however, are his Buddhas transcendental creatures with a will, such as Amitābha in the popular version of the Pure Land tradition. Rather than to indicate persons at all, I argue, the word refers to a certain awareness, an understanding 
of reality such as it is, for itself, which necessarily implies the dissolution of a binary relationship with it. "Buddhas and ancestors" are thus originally (human) beings, who have achieved such a state of mind and are abiding in it, which, in turn, makes it impossible to assign any kind of individual subjectivity to them. When they say something, as they often do in the passages Dōgen quotes, they are not really separate from what they are saying. A particular phrase occurs in a particular situation, in an encounter that fuses the minds of both sides of the transmission, but it is actually always that state of mind in full, not an expression, an actualization or a manifestation of it. This, indeed, is one of Dōgen's key points, captured by Bret Davis's precise characterization of his thought as "egoless perspectivism" (Davis 2011): universality is accessible only as a particularity.

"Picking out" points to the confirmation (or rejection) of someone else's understanding in an encounter between a teacher and a disciple, something that so many Zen stories are concerned with, and indeed, the notion of dottoku is used in the fascicle in close conjunction with two other concepts, which use the characters "to see" and "to witness" in the place of "way/to speak", primarily indicating the understanding or recognition of the other's attainment. In Dōgen's usage, however, these, too, turn into "seeing-as-attainment" and "recognition-as-attainment":

At a time like this, the attainment-expression is not interrupted for many decades. As this is so, the seeing-as-attainment at moments of exhaustive realization must be genuine. Because the seeing-as-attainment of those moments [in the past] is regarded as genuine, the attainment-expression of the present is without doubt. Therefore, the attainment-expression of the present has provided the conditions for the seeing-as-attainment of the past. The seeing-as-attainment of the past has provided the conditions for the attainment-expression of the present. This is why there is attainmentexpression in the present, seeing-as-attainment in the present. The attainment-expression of the present and the seeing-as-attainment of the past are a single line, ten thousand miles long. The practice of the present is accordingly the continuous practice of both attainment-expression and seeing-as-attainment. (Dōgen 1972, vol. I, pp. 384-85)

The question for us here is whether we should read this passage as a discussion of the practice of a single individual or of the transmission that the previous passage was talking about. For Dōgen, however, there is no such distinction. In an often-quoted passage of "A Talk on Discerning the Way" (辨道話 Bendōwa), he has introduced the idea of what could be termed "imperceptible sharing":

It might be just one person doing zazen at just one moment, but because of the mutual integration with all existents and the interpenetration of all moments in time, in the inexhaustible dharma-realm, in the past, future and present, they are constantly participating in the transformative work of the Buddha-way. (Dōgen 1972, vol. I, p. 15)

The mind of someone sitting in meditation reaches out to the mind of everything else in the universe and the enlightened minds of all others reach back to them, supporting them in their endeavor. This indeed sounds suspiciously like a mystical experience of communicating with the minds of all beings throughout the universe, including its past and future. But this, too, can be rationalized: for example, when following the steps of proof of a mathematical theorem, we can imagine that our mind is connected to the one that first conceived of it, as well as anybody else's who has followed and understood it since, because mathematical truths, as it is well known, have no actual referent outside the mind. Similarly, when reading a poem, we can feel connected to the mind of its author, even if long dead-indeed, such imperceptible sharing is the very foundation on which any kind of such aesthetic communication (however incomplete and individual the resulting interpretation is) has to be based. 
It should not be difficult to imagine a universalization of this experience when we substitute concentration on the absence of semantic content for mathematical, poetic, or other kinds of ideas. The point, in other words, is not in establishing a communion with some other, transcendentally existing beings, or even in communicating telepathically with other minds, but in the opening up of one's subjective internality and reconceptualizing it as a coming-together of multiple heterogeneous streams of thought of the past and present. In fact, as Dōgen says, "'always' is a temporal part of every single moment" (Dōgen 1972, vol. II, p. 63). This makes possible an understanding that a single and separate individual, opposing themself to the rest of the world and therefore refusing to stand on the shoulders of giants or anyone else, is never able to achieve. Dōgen says as much in the "The Eihei Transcripts" (永平公録 Eihei kōroku I 11): "Coming together [to study] in immediate suchness, that is being with all the Buddhas. Coming together [to study] without the immediate suchness, that is being with one's own self." In a sense, then, we can interpret the "Buddhas and ancestors" simply as a term referring to the presence of significant others in our consciousness, and think of "Buddha-words" or butsugon as any verbalized expressions capable of altering our behavior in a way that we ourselves will go on to consistently approve of ${ }^{7}$. Any quotation, by anyone, remembered from anywhere, may become a Buddha-word if we recall it at an appropriate moment. Even a platitude posted by someone on Facebook may perform a revelational role, if we happen on it in a corresponding state of mind and let it change the way we react to and act upon our environment.

To return to the issue at hand: in successful praxis, the distinction between the other and the self is no longer relevant, which is why the question of whether the "attainment-understanding" of the past is one's own or someone else's should not even arise. What we have is the lack of interruption of both one's own practice and the transmitted realization. At this point, we have a glimpse of a rare moment of doubt in Dōgen's writing, when he resorts to a slightly awkward logical construction to justify his belief that authentic transmission must be possible. The imperceptible sharing between minds, going on without interruption, is presented to his assembly as an argument for the truth of what an individual can realize. We can, of course, turn the argument around and say that whatever an individual genuinely experiences is the personal truth for that individual, but that is hardly what Dōgen would have meant here, believing in the possibility of authentic, mind-to-mind transmission as he does. And yet, the construction is presented as a conditional: it is because we regard the past attainment-understanding as genuine that the present attainment-expression should not be doubted either.

This evolves seamlessly into the view that the transmitted understanding and the present expression are the prerequisites of each other. What is interesting here is that the present is primarily the necessary condition of the past-but indeed, if nobody were to read a poem or study mathematics in the present, the past understandings that lie at their base would not have any actuality. By connecting to them, we credit them with the agency to cause the mental states that we experience at this moment, in which the expression and understanding are fused into one and take the form of a continuity. In Dōgen's thought, this inherence of the past in the present is characteristic of all existence, which is made up of "traces" of the past, somewhat similarly to the sense that Jacques Derrida gives to this word:

The living present springs forth out of its nonidentity with itself and from the possibility of a retentional trace. It is always already a trace. This trace cannot be thought out on the basis of a simple present whose life would be within itself; the self of the living present is primordially a trace. The trace is not an attribute; we cannot say that the self of the living present "primordially is" it. Being-primordial must be thought on the basis of the trace, and not the reverse. (Derrida 1973, p. 85) 
However, when we look at Dōgen's idea of "expression" in this context, it seems to be quite far removed from language or anything linguistic, and much closer to a theory of the perfect mental state, with a dialectic of active and passive aspects. "Expression" is perhaps not necessarily about communication at all. Indeed, Dōgen's notion of perfect language is opposed neither to human silence (intentional, and therefore communicative, not-speech), non-verbal ways of communication (un-speech), the absence of a communicative relation to speaking (muteness, or no-speech in the usual sense of the word), nor even to situations where no communication would normally be imagined at all-that is, the real world just being what it is (zero-speech). Moreover, the hypothetical binaries that emerge from this paradigm all reinforce each other by bringing their own particular tensions into all others. For example, in "Attainment-expression", he writes:

Someone can thus be mute, but still abide in attainment-expression, therefore do not think that mutes have no attainment-expression at all. And those who have attainment-expression are not necessarily not mute. Mute persons also have attainment-expressions. The mute voice should be audible, the mute words should be heard. If you are not mute, how can you achieve a mutual understanding with someone who is mute? How can you have a dialogue with such a person? But if you are a mute person yourself, how is your mutual understanding born? How is your dialogue born? (Dōgen 1972, vol. I, pp. 386-87)

Needless to say, Dōgen is not talking about grimaces, gesticulation, or any other kind of un-speech here, but strictly of non-speech, a communicative situation where no channel of communication whatsoever is available and which the knowledge of any kind of sign language would be unlikely to resolve-but transmission occurs nonetheless. "The mute voice," "the mute words" refer to nothing other than the expression that takes place in the absence of any signifying system-and this is something that can only be properly received when one rids oneself of any efforts to use signifying systems for understanding it. What we have in "non-speech" is, so to say, a second-level negative that denies the circumstances where first-level negation is possible in principle ${ }^{8}$. It is only with the help of such a second-level negative that one can accomplish the task that Tsunoda Tairyu has formulated for language, thus understood, and namely, to express absolute unity with the help of a language relying on binary oppositions (Tsunoda 1999, pp. 135-36).

To describe this communicative situation from the point of view of the recipient, Dōgen extracts, in the "Transcending the Buddha" (佛向上事 Bukkō jōji) fascicle, the neologism "precisely-hearing" (即聞 sokubun) from a conversation between Dongshan and a monk. In the original text, the word translated as "precisely" is used in its ordinary meaning of "already", but Dōgen assigns to it the terminological meaning in which it is used, for example, in the well-known passages of "The Heart Sutra": "form precisely-is emptiness, emptiness precisely-is form" ${ }^{\prime}$. In these expressions, "precisely" or "immediately" refers to something we might call pre-predicative sameness, in contrast with a situation of predication where an " $A$ " is said to be a " $B$ ", so that predication points the sameness out, while $A$ and $B$, the referents of " $A$ " and " $B$ ", respectively, can occur in the world without their sameness being immediately obvious. Analogically, "precisely-hearing" designates the moment when someone realizes that the content of a message is something they have known all along, on a much deeper level, without, however, having been aware of this knowledge. Or, as Terada Tōru puts it, the voice of ultimate knowledge is, according to Dōgen, nothing other than the very framework of our consciousness itself (Terada 1974, p. 81).

It is perhaps obvious by now that the opposition between the perfect language of "expression" and its negatives bears a significant resemblance to the "non-thinking" that Dōgen names as the core of praxis, when he quotes an anecdote in the "The needle of praxis" (坐禪筬 Zazenshin) fascicle: 
Great master Yaoshan Hongdao was sitting, when a monk asked: "What is a motionless thought?"

The master said: "It is the thought [that occurs] during not-thinking."

The monk said: "What kind of thoughts do you have during not-thinking?"

The master said: "Non-thoughts". (Dōgen 1972, vol. I, p. 127)

The ordinary way to interpret the monk's first question would be the much more natural "What are you thinking about, sitting so motionlessly?" It should also be noted that the original does not linguistically distinguish between "thinking" and "thought", the process and its result; thus, "non-thinking" is more properly translated as "non-thought", especially as the "non" in this compound, 非 hi, is the word of Classical Chinese used in sentences negating entities, not verbs, as in "Mary is not a girl" (but, for example, a boat).

We can find the term "non-thinking" in quite a few earlier texts; for example, in the Mahāratnakütasütra, it is used to characterize a particularly difficult and deep teaching that reaches into the "domain of non-thinking" (Takakusu and Watanabe 1961b, vol. 11, p. 0410c04). What seems to have occurred within the Chinese tradition, however, is the emergence of a philosophically weighted opposition between two negatives, which the Chinese language makes available, namely fu 不 and $h i$ 非. The two convey a different kind of negativity: $f u$ is the "contrary" negative, to borrow terms from Greimas (1987, p. 49), stating that the action characterized by it does not take place, while hi represents a "contradictory" negative, which opposes the word it characterizes to how we normally understand $\mathrm{it}^{10}$. For example, when someone is intoxicated and decides not to use their car, this would be fu-driving, because the act of "driving" does not take place. Sitting behind the wheel in the circumstances, on the other hand, would be hi-driving, because this act completely ignores the rules and regulations under which "driving" should properly happen. Similarly—as can also be inferred from the quoted story-hi-thinking is not the absence of any mental activity whatsoever, but something that does not correspond to the accepted definition of what "thinking" means. Thus, we might interpret shiryō more appropriately as "thinking with measures", or "thinking in quantities", while fushiryō would then be "the unthinkable-unmeasurable" and hishiryō "thinking not with measures, not in quantities".

This second-order negative is a constant presence in Dōgen's (or, for that matter, most Buddhist philosophical) thought, and therefore it seems justified to invoke it also here as a characteristic of his perfect language, or the "attainment-expression" that does not translate into a first-level communicative act. Indeed, if the entire reality is, so to say, attainment-expressional, then the communication of this fact cannot rely on binary oppositions, or first-level negatives, as these inevitably "illuminate one side, leaving the other in the dark", as Dōgen puts it in "The Challenge of Immanent Becoming" (現成公案 Genjōkōan, Dōgen 1972, vol. I, p. 35). But this has no bearing on the second-level negative, which is a permanent presence in everything that exists, as nothing ever stays in a determinable state for longer than a dimensionless moment (see Raud 2012). In the apt words of Catherine Malabou, "everything that comes into presence arrives changed, substituting itself for itself. This is the original ontological phantasm. Presence originally exchanges itself in return for its modification" (Malabou 2010, p. 31). What "perfect language" performs is the communication of this fact.

Is this rational? Absolutely, especially if we take the pedagogical context of transmission into account. Contemporary educational science has long since abandoned the idea of replicating, in children, the knowledge and attitudes of the teachers, and has replaced this with the task of "creating people who are capable of thinking and doing new things, not simply repeating what past generations have done, but equipped for a world of challenge and change" (Fisher 2004, p. 11). This means that the object 
of communication is not a "what", but a "how", a realization, a state of mind not received from the outside, but developed internally in the learning process. The idea that a transmission can occur between two minds without any definable or semantically describable "what" being transmitted is thus not only rational, but forms one of the cornerstones of the teaching process as it is understood in our times.

\section{Dynamic Being as Self-Expression}

All of this still leaves us with the other half of the question-if reality is itself significant as "non-speech", then who is doing the signifying? Some previous pansemioticist theories, such as Kükai's, posit a subjective Other to whom this activity is attributed, but Dōgen's view is even more radical. In this section, I am going to argue that, for Dōgen, the very availability of meaningful experience as such is in itself a linguistic phenomenon - that reality, as it confronts us, is not simply meaningful and significant, but quite actually consists in signification.

Signification should, let me emphasize, be understood in Dōgen's theory not as something an agent does, but as the way in which everything is. Dōgen's idea of dynamic being (cf. Raud 2015) can indeed be understood not simply as constant becoming-oneself, but more specifically becoming-oneself-for-another, so that all being is by itself meaningful.

Thus, if, in a communicative situation, we still need to imagine another party with which the dialogue takes place, then, as argued by Dōgen in the "Insentient expounding of the dharma" (無情説法 Mujō seppō) fascicle, reality consists in such signification that happens without there being any consciously signifying party behind it. There is, he writes, a fundamental quasi-linguistic activity at work in all being. As Yorizumi Mitsuko has noted, in opposition to the ordinary language used in daily communication, a language which, so to say, follows from reality, Dōgen also postulates another kind of language that transcends this ordinary level and precedes reality-and such language does not speak about reality, it speaks reality itself (Yorizumi 2014, pp. 61-62). In other words, expression—which is expressing itselfis precisely the dynamism that keeps reality up and running:

Expounding the dharma by expounding the dharma is the immanent challenge that is conferred to Buddhas and ancestors by Buddhas and ancestors. This expounding of the dharma is what the dharma itself expounds. It is not sentient, it is not insentient. It is not with purpose, it is not without purpose. It does not rely on a causal chain linking with-purpose and withoutpurpose, it has not emerged because of causal chains from the past. [ ... ] Since before the time of all Buddhas, expounding of the dharma has continued as the primary activity. You should not think that expounding of the dharma continues as established by the Buddhas and the ancestors. It is the Buddhas and the ancestors that have been established by this expounding of the dharma. (Dōgen 1972, vol. II, p. 61)

Even though this term consists of two separate words, Dōgen immediately lets us know that it is the dharma itself that does the expounding and thus is not the object of some other agent's discourse. It is something always present when the transmission from mind to mind occurs, and even though the founding myth of Chan/Zen opposes the silent message of the Buddha upholding the flower to verbal explanations of the doctrine, Dōgen insists that expounding the dharma is similarly present in that very act as well. This is the fundamental activity of the universe and the mind that can have a direct (Dōgen often uses the word "intimate") relationship to it is one of its by-products. This primordial signification stands outside causal chains and is independent of dichotomies, including the differentiation between signifier and signified, which, in one way or another, lies at the bottom of most Western theories of meaning. In short, it is the becoming-available of the conditions of meaningful experience that have been designated by this term. The dynamism of being implies 
signification for this very reason: any existence can be conceived of only from a specific perspective-as stated above, one of Dōgen's central ideas is that the universal is only ever accessible as the particular. Consequently, whatever happens becomes real by becoming meaningful, at least from a heuristically conceivable perspective. This is beautifully captured in verse in "The Eihei Transcripts" (X 102):

When I love the mountains, the mountains love me back as their master.

When big rocks are big and small ones small, how would they ever stop talking?

"The master" here refers to the thing-forming gaze, the holder of the perspective from which mountains appear as mountains, and similarly there has to be a vantage point from which "big" rocks appear to be "big" and "small" ones "small"embeddedness in what is thus becomes a prerequisite for embracing its pansemiotic dynamism.

This meaningfulness of nature does not imply an abstract relationship with an ideal or cosmic "reality" and the mind of an individual person, but pertains primarily to the very concrete level of navigating our immediate environment. "The mountains and waters of the absolute present are how the way/words of ancient buddhas become immanent ... As a message from before the aeon of emptiness, they are the livingness of the absolute present", Dōgen writes in the "Landscape as Scripture" (山水經 Sansuikyō) fascicle (Dōgen 1972, vol. I, p. 331). The expression "how the way/words of ancient buddhas become immanent" (doggenjo 道現成) again makes use of the ambivalence of the word do 道, which can be read both as "way" and as "saying": there is indeed no "way" apart from "language", the two are synonymous, actions are also expressions. As Hee-jin Kim has argued, "the range of the functions of language (in its broadest sense, as Dōgen understood it) became coextensive with that of human activities ... language and activity were inseparably one in his thought" (Kim 2004, p. 82). Ralf Müller adds that this concept entailed not only the verbal, aesthetic, or moral expressions of human beings, but also, and importantly, the manifestations of the non-human and non-living world (2013, p. 189). As Morimoto Kazuo points out, however, it would be incorrect to assume that Dōgen is speaking about "reality as language", bringing together two phenomena initially apart from each other, because there is no difference: reality is language; there is no ground to make a distinction between things/processes, actions, and words (Morimoto 1999, pp. 92-93).

In short, language-which is a shorthand for any conceptual system-and the reality it supposedly reflects are, in fact, non-dual. Thinking of "reflecting" here already means we are getting it wrong. A conceptual system, moreover, is not to be thought of as a rigid and self-identical structure, but a totality that can accommodate contradictions and tensions just as easily as smooth continuities.

To say that reality consists in signification may again seem to be a mystical view, which ascribes to reality certain features that are grounded in the observing consciousness. And yet, on closer investigation, it should appear no more otherworldly than the belief, shared by quite a few Western thinkers of different backgrounds, that reality has a logical structure that natural languages reflect- "Being that can be understood is language," as Hans-Georg Gadamer has famously (and emphatically) said (Gadamer 2004, p. 470). Others, such as Charles Sanders Peirce, are even more strongly committed to pansemioticism, insisting that semiosis, or the production of signs, is a primary characteristic of how the world-process works ${ }^{11}$. The work of influential biosemioticists, following this lead, has indeed shown that sign production is an essential aspect of various processes going on in the natural world (Kull and Emmeche 2011). On a yet deeper level, all forms of life can be seen to rely on certain kinds of codes, such as DNA, as semiotically inclined thinkers have also been quick to notice. Thus, Roman Jakobson states that "among all the information-carrying systems, the genetic code and the verbal code are the only ones based upon the use of discrete components which, by themselves, are devoid of inherent meaning but serve 
to constitute the minimal senseful units, i.e., entities endowed with their own, intrinsic meaning in the given code" and goes on to point out that both these languages function similarly, as systems of binary oppositions" (Jakobson 1971, p. 679). Based on this view, it is not difficult to construe a view according to which the world is in fact "speech" that uses the vocabulary of elementary particles combining with each other according to the grammar of physics or nature more broadly. The only thing absent from this picture is a speaker. But neither is one to be found in Dōgen's world, where the "expounding of the dharma is what dharma itself expounds". Many centuries later, a structurally rather similar view is reiterated by Martin Heidegger:

We would reflect on language itself, and on language only. Language itself is-language and nothing else besides. Language itself is language. The understanding that is schooled in logic, thinking of everything in terms of calculation and hence usually overbearing, calls this proposition an empty tautology. Merely to say the identical thing twice-language is languagehow is that supposed to get us anywhere? But we do not want to get anywhere. We would like only, for once, to get to just where we are already.

This is why we ponder the question, "What about language itself?" This is why we ask, "In what way does language occur as language?" We answer: Language speaks. Is this, seriously, an answer? Presumably-that is, when it becomes clear what speaking is. (Heidegger 2001, p. 188)

There is, however, an important difference between all these theories and the views of Dōgen. Western pansemioticism sees the semiosis of the world as the workings of an unequivocal code, which is producing self-identical meanings, in theory repeatable from one context to another without overly heavy losses. Dōgen's view is different. For him, each attainment-expression is anchored in its own unrepeatable present, and even if the words (the gon-level language) might be the same, they mean something different each time they are uttered: "Do not think that the expounding of the dharma of the Buddhas of before is the expounding of the dharma of the Buddhas of after. Just as the Buddhas of before do not become the Buddhas of after, so also in the case of expounding the dharma the expounding of before does not transform into the expounding of after" (Dōgen 1972, vol. II, p. 61). In fact, this follows necessarily from Dōgen's views on time and reality (see Raud 2012). Clearly, this also serves as a legitimizing strategy for Dōgen's own textual praxis: whatever he reads into a particular expression at a particular moment necessarily has to be a part of the meaning of that expression at that moment. Adequate communication is either total or does not take place at all.

One example of such communication that Doggen often brings up is the story of Bodhidharma's transmission, in which four monks are examined. Three of these summarize their understanding of Chan/Zen in competing sentences, but Huike just bows three times and goes back to his place. On the basis of this, Bodhidharma entrusts the leadership of his school to him. The usual interpretation of this story is that while the first three may have understood the teaching to some extent, Huike's grasp is superior to all of them. Metaphorically, the first three are told to have attained the teacher's skin, flesh, and bones, but Huike is the one who has attained the marrow. Dōgen disagrees. In "The Vines Entwined" (葛藤 Kattō) fascicle of “The Core Transmission", he unambiguously explains that the silent answer of Huike was no better than all the others. In the "Attainment-expression", he provides more detail:

... when an attainment-expression expresses attainment, the not-expression remains unuttered. Even if we do recognize that attainment is being expressed, but the state of mind of the not-expressed is not yet reached, it still is not the face of Buddhas and ancestors, it is not the bones and marrow of Buddhas and ancestors. Therefore, how could the state of mind expressed in the "three bows and returning to one's place" be the same as the the state 
of mind expressed by the "skin-flesh-bones-marrow"-fellows? The the state of mind expressed by the "skin-flesh-bones-marrow"-fellows has no way to touch the attainment-expression of "three bows and returning to one's place", it has no way to provide the conditions for it. (Dōgen 1972, vol. I, p. 385)

The first sentence of this passage brings to mind Wittgenstein's famous finishing sentence or the Tractatus Logico-Philosophicus (7): "What we cannot speak about we must pass over in silence" (Wittgenstein 2001, p. 89). For early Wittgenstein, that silence has to cover the domain that cannot be analyzed with the tools of logic. For Dōgen, the ground of the not-expressed necessarily has to be reached by understanding in order for the latter to be adequate. Note that the level of understanding criticized in this passage is not that of the first three monks (compared to "skin", "flesh", and "bones"), but the "skin-flesh-bones-marrow" fellows- that is, all those who insist on distinguishing between the four and want to organize levels of understanding into a hierarchy.

This quality that all adequate expressions possess cannot be reduced to its perceptible form or even to the "channel" through which signification is being transmitted, as stated in the "Insentient expounding" fascicle:

Do not think that the proper form of insentient expounding is necessarily unlike the one of the sentient one. Because it is similar to the voice of the sentients as well as the proper form of sentient expounding, it is not the case that when we remove the voices of the sentient world, we get to the voices of the insentient world. The insentient expounding of the dharma is not necessarily a part of the voice-domain at all. By analogy, it seems that the sentient expounding of the dharma is not a part of the voice-domain either. (Dōgen 1972, vol. II, p. 63)

Later in the same fascicle, Dōgen goes on to say that the expounding voice should not be heard by the ears, but the eyes; this does not mean that seeing is more important than hearing - the key to comprehension in fact consists in letting go of all our first-order signifying faculties:

On the whole, listening to the dharma is not limited to the voice-perceptions and voice-consciousness... You listen to the dharma with your body first and your mind second... Don't say that there is no use in listening to the dharma if it does not connect to your mind-consciousness. It is those who extinguish their minds and get rid of their bodies who are able to benefit from listening to the dharma. Those with no mind and no body are able to benefit from listening to the dharma. All Buddhas and all ancestors, shifting through their moments like this, made themselves Buddhas and became ancestors. (Dōgen 1972, vol. II, p. 67)

In short, if we keep clinging to the structuralist understanding of language based on binary oppositions, which rely on first-level negatives, we are missing its point-it is the second-level negative, transcending and absorbing the first level-incidentally also the level of opposable "bodies" and "minds" that are, again, radically separate from other "bodies" and "minds"- that the meaningfulness of reality as such is disclosed.

\section{Conclusions}

In this article, I have argued that for Dōgen, the very availability of a meaningful experience of reality is in itself a linguistic phenomenon. Verbal language is therefore not an inferior form of expression compared to profound and allegedly banalitytranscending silence: both of these need to be grounded in a more primordial immediacy of understanding that is unique at every single moment, and yet both recognizable and transmissible. This is why not-speech, zero-speech, and un-speech are all 
fundamentally linguistic inasmuch they can be interpreted as expressions. Therefore, they do not essentially differ from code-based signifying systems-at least as far as the communication of essentials, reliant on non-speech, is concerned. Such communication is a primordial feature of all of reality. However, it does not emanate from a transcendental subject, someone with a will, a body, a personal history-in short, a divine Other to whom we would have to look up. This signifying activity is the dynamic arrangement of being itself. All ways in which we can designate the entities through which such communication reaches us are therefore just heuristic. This is because these entities are not the points of origin of the expressions in question, but the results, the outer forms of particular segments of the expressive process. Ordinary verbal language is thus not to be disdained, but also not to be taken at face value. Whenever it works as a vehicle for the communication of essentials, what it carries is not immediately visible to the idle eye, but is accessible only as a result of an effort that totally engages the recipient person's resources, physical and mental. That, it seems, is also the way Dōgen intended his own work to be read.

Funding: This research received no external funding.

Institutional Review Board Statement: Not applicable.

Informed Consent Statement: Not applicable.

Data Availability Statement: Not applicable.

Acknowledgments: I would like to thank the anonymous reviewers of the first draft of this article for many helpful comments.

Conflicts of Interest: The author declares no conflict of interest.

\section{Notes}

1 Thus, for example, Vasubandhu's case against objective reality (Vasubandhu 1999, pp. 393-94) is fully rational even if we do not believe in the existence of the figures involved the example: if hell is real, Vasubandhu argues, then the demons of hell have to be reincarnations of certain sentient beings and not imaginary creatures, but the very idea of hell consists in that beings are confined to it because of unwholesome karma; and yet the demons thoroughly enjoy themselves in torturing other beings, which means they are not there for punishment. Therefore, the reality of hell cannot be objectively the same for all beings in it. But if this is so for hell, then it is only reasonable to think that all domains of existence work in the same way. We should not dismiss the ideas of Vasubandhu (or Dōgen) as irrational simply because they take the commonsensical beliefs of their days as their point of departure; on the contrary, this should lead us to see how rational argument has, throughout history, often been a powerful tool challenging the commonsensical status of such beliefs.

2 I use the word "praxis" to denote the difference Dōgen makes (Dōgen 1972, vol. II, p. 224) between "zazen of the body" (which I translate as "practice"), the participation in formalized activities and the simple performance of duties, and "zazen of the mind" (translated as "praxis"), any abiding in the state that Doggen equates with enlightenment.

3 The universal and the particular may sound like specifically Western philosophical concepts, but their opposition is inherent in both of the main intellectual paradigms of East Asian Buddhism of that time, namely the Tiantai doctrine of "three thousand worlds in a single thought-moment" (see Ziporyn 2016, p. 156ff. for a more detailed discussion), as well as the Huayan paired concepts of 理 $l i$ and 事 shi. Dōgen offers his own treatment of the issue in the 仏性 Bussho (Buddha-nature) fascicle of "The Core Transmission".

4 For clarity, it should be noted that Ishii does not interpret the notion of uji as momentary existence in the way I do.

5 The usual way to translate the title of Dōgen's main work as "Treasury of the True Dharma Eye" is yet another example of mystifying exoticizing. The expression shōboggenzō is taken from the founding myth of Chan/Zen, or the incident where Buddha upheld a flower in front of his disciples and only Mahākāyapa was able to respond with a spontaneous smile. At this, the Buddha decided that it was to Mahākāyapa that he would transmit the (secret) core of his teaching, or shōbogenzō. What Dōgen's title implies is that the essays in his book contain the same message that the Buddha imparted to Mahākāyapa and that had been transmitted by Chan/Zen lineages to his day. It is particularly wrong to translate 蔵 $z \bar{o}$ as "treasury" in this context. The 
original primary meaning of the Chinese word is "to keep from others, to hide", from which "storehouse" is derived, and here the word clearly refers simply to something hidden from others; in the Buddhist context, it also plays with the fact that the character is used to translate the Sanskrit pitaka (as in Tripitaka), so Dōgen also likens his essays and lectures to canonic texts.

6 All translations of passages from Dōgen's works are my own.

7 We should note that this is not an exclusively positive phenomenon. Thus, "mind share" is a term used in advertising theory, which points to the effect of colonizing the minds of prospective customers by establishing a brand name in their consciousness as the first and foremost association with some of their needs or behavioural patterns. It could be argued that "mind share" harnesses the same psychological mechanism that Dōgen's imperceptible sharing refers to, and the even more extreme cases of being brainwashed, for example, into wholeheartedly endorsing a terrorist ideology again rely on the same capacity of the human mind to open itself up and feel a communion with other minds or external others that acquire an overwhelming significance in the process.

8 When we hear someone speak, but are able to infer from their unintentional self-expression that what they actually want to say is something quite different, if not the opposite of what their words mean, we are hearing their speech and non-speech simultaneously. Superb acting also often relies on non-speech, which springs forth form the actor's internalized grasp of their role. It is thus again hardly a mystical communion between elevated minds, but a phenomenon frequently met in daily social situations.

9 See Raud 2003 for a discussion of how this term has emerged out of a translation mistake.

10 These negatives most probably reflect the distinction of "affirming" and "non-affirming" negations in Indian Buddhist thought, as pointed out by one of the anonymous reviewers of this article.

11 "It seems a strange thing, when one comes to ponder over it, that a sign should leave its interpreter to supply a part of its meaning; but the explanation of the phenomenon lies in the fact that the entire universe-not merely the universe of existents, but all that wider universe, embracing the universe of existents as a part, the universe which we are all accustomed to refer to as "the truth" - that all this universe is perfused with signs, if it is not composed exclusively of signs" (Peirce 1960, vol. 5, p. 448).

\section{References}

Abe, Ryūichi. 1999. The Weaving of Mantra: Kūkai and the Construction of Esoteric Buddhist Discourse. New York: Columbia University Press.

Dallh, Minlib. 2018. 'Dōgen and Meister Eckhart on Detachment/Non-Attachment'. Medieval Mystical Theology 27: 22-35. [CrossRef]

Davis, Bret W. 2011. The Philosophy of Zen Master Dōgen: Egoless Perspectivism. In The Oxford Handbook of World Philosophy. Edited by William Edelglass and Jay L. Garfield. Oxford: Oxford University Press.

Derrida, Jacques. 1973. Speech and Phenomena, and Other Essays on Husserl's Theory of Signs. Translated by David B. Allison, and Newton Garver. Evanston: Northwestern University Press.

Dōgen. 1972. Dōgen. Nihon Shisō Taikei 12-13. Edited by Tōru Terada and Yaeko Mizuno. Tokyo: Iwanami.

Fisher, Robert. 2004. What Is Creativity? In Unlocking Creativity Teaching Across the Curriculum. Edited by Robert Fisher and Mary Williams. Abingdon: David Fulton Publishers.

Gadamer, Hans-Georg. 2004. Truth and Method. Translated by Joel Weinsheimer, and Donald G. Marshall. London and New York: Continuum.

Greimas, Algirdas Julien. 1987. On Meaning: Selected Writings in Semiotic Theory. Theory and History of Literature. Minneapolis: University of Minnesota Press.

Hakeda, Yoshito S. 1972. Kūkai: Major Works. New York: Columbia University Press.

Heidegger, Martin. 2001. Poetry, Language, Thought. New York: HarperCollins.

Ishii, Kyōji. 2001. Shōbōgenzō no Sekai. Tōkyō: Kawade shobō.

Jakobson, Roman. 1971. Selected Writings: Word and Language. The Hague: De Gruyter Mouton.

Kim, Hee-Jin. 2004. Eihei Dōgen: Mystical Realist. Boston: Wisdom Publications.

Kull, Kalevi, and Claus Emmeche, eds. 2011. Towards a Semiotic Biology: Life Is the Action of Signs. London, Singapore, Hackensack: Imperial College Press.

Malabou, Catherine. 2010. Plasticity at the Dusk of Writing: Dialectic, Destruction, Deconstruction. Translated by Carolyn Shread. New York and Chichester: Columbia University Press.

Morimoto, Kazuo. 1999. Derida kara Dōgen e. Tōkyō: Chikuma Shobō.

Müller, Ralf. 2013. Dōgens Sprachdenken. Historische und Symboltheoretische Perspektiven. München: Karl Alber.

Nagatomo, Shigenori. 2000. The Logic of the Diamond Sutra: A Is Not A, Therefore It Is A. Asian Philosophy 10: 213-44. [CrossRef]

Peirce, Charles S. 1960. Collected Papers. Cambridge: Belknap Press of Harvard University Press.

Raud, Rein. 2012. The Existential Moment: Rereading Dōgen's Theory of Time. Philosophy East and West 62: 153-73. [CrossRef]

Raud, Rein. 2013. Thinking with Dōgen: Reading Philosophically into and beyond the Textual Surface. In Philosophizing in Asia. Edited by Tsuyoshi Ishii and Lam Wing-Keung. Tōkyō: UTCP, pp. 27-46. 
Raud, Rein. 2015. Dōgen's Idea of Buddha-Nature: Dynamism and Non-Referentiality. Asian Philosophy 25: 1-14. [CrossRef]

Raud, Rein. 2019. Landscape as Scripture: Dōgen's Concept of Meaningful Nature. In Philosophies of Place: An Intercultural Conversation. Edited by Peter D. Hershock and Roger T. Ames. Honolulu: University of Hawaii Press, pp. 177-92.

Ruhl, Steve. 2020. Enlightened Contemporaries: Francis, Dōgen, \& Rūmī: Three Great Mystics of the Thirteenth Century and Why They Matter Today. Rhinebeck, New York: Monkfish Book Publishing Company.

Takakusu, Junjirō, and Kaigyoku Watanabe, eds. 1961a. Mahāparinirvānasūtra. In Taishō Taizōkyō. Tokyo: Taishō Shinshū Daizōkyō Kankōkai, vol. 12, No. 374.

Takakusu, Junjirōo, and Kaigyoku Watanabe, eds. 1961b. Mahāratnakūtasūtra. In Taishō Taizōkyō. Tokyo: Taishō Shinshū Daizōkyō Kankōkai, vol. 11, No. 310.

Terada, Tōru. 1974. Dōgen no Gengoteki Uchū. Tōkyō: Iwanami.

Tsunoda, Tairyū. 1999. Dōgen Nyūmon. Tōkyō: Kadokawa.

Van Norden, Bryan W. 2017. Taking Back Philosophy: A Multicultural Manifesto. New York: Columbia University Press.

Vasubandhu. 1999. Twenty Verses on Consciousness Only. In Three Texts on Consciousness Only. BDK English Tripitaka 60-I, II, III. Translated by Francis Harold Cook. Berkeley: Numata Center for Buddhist Translation and Research.

Wittgenstein, Ludwig. 1975. Philosophical Remarks. Edited by Rush Rhees. Translated by Raymond Hargreaves, and Roger White. Oxford: Basil Blackwell.

Wittgenstein, Ludwig. 2001. Tractatus Logico-Philosophicus. Translated by David F. Pears, and Brian F. McGuinness. Routledge Classics. London and New York: Routledge.

Yorizumi, Mitsuko. 2014. Shōbōgenzō Nyūmon. Tōkyō: Kadokawa.

Zelinski, Daniel. 2007. From Prudence to Morality: A Case for the Morality of Some Forms of Nondualistic Mysticism. Journal of Religious Ethics 35: 291-317. [CrossRef]

Zengaku Daijiten Hensanjo. 1985. Shimpen Zengaku Daijiten. Tōkyō: Taishūkan Shoten.

Ziporyn, Brook A. 2016. Emptiness and Omnipresence: An Essential Introduction to Tiantai Buddhism. Bloomington: Indiana University Press. 